\title{
Effect of Fiscal Independence and Local Revenue Against Human Development Index
}

\author{
Ayu Kurnia Sari ${ }^{1}$, Hendra Saputra $^{2}$, Andysah Putera Utama Siahaan ${ }^{3}$ \\ ${ }^{1,2}$ Faculty of Economics and Business \\ ${ }^{3}$ Faculty of Computer Science \\ Universitas Pembangunan Panca Budi Jl. Jend. Gatot Subroto Km. 4,5 Sei Sikambing, 20122, Medan, Sumatera \\ Utara, Indonesia
}

\begin{abstract}
Local revenue is intended to finance infrastructure and basic public services that have not reached a certain standard to accelerate regional development. Capital expenditure is to increase public facilities. No part of the Capital Expenditure used for operational costs such as the construction of travel expenses and so on. Human Development Index is a measure of comparison of life expectancy, education and standard of living for all countries around the world. Human Development Index is used to classify whether a country is a developed country, developing or underdeveloped countries and also to measure the impact of economic policies on quality of life. If a public facility can be met, then people feel comfortable and be able to run their business efficiently and effectively so that in the end will create a healthy life and a longer life expectancy as well as partially and simultaneously improve the quality of education and standard of life of the community. Data was collected from 33 District Municipality (25 districts and eight cities) in the district/cities of North Sumatera. The sample used in this study were 22 district/cities (15 District and 7 Cities), from 2005 to 2009. Moreover, the fiscal independence level affects indirectly to the Human Development Index.
\end{abstract}

Keywords: Fiscal Independence Level, Local Revenue, Capital Expenditures, Human Development Index

\section{INTRODUCTION}

In the implementation of regional autonomy, each district/city is expected to be able to explore optimal financial resources, manage, and use its funds to finance the operation of government. Thus the implementation of regional autonomy will allow fiscal independence for the district/city. By creating local fiscal autonomy, local governments will be able to finance regional development by the purpose of involving the interests of the region without a center or central government intervention in the development process in the region [2][3].

An indication of success is the increased regional autonomy and social welfare services, a democracy that is more advanced, their sense of justice, equity, and their harmonious relationship vertically between the central and regional as well as horizontal relations between the regions [1][6]. That view fits with the direction of the authority that covers all areas of government in the framework of regional autonomy. Another purpose of the implementation of regional autonomy from the central government is freeing unnecessary burden and encouraging initiatives and the ability of the area so that the area becomes more self-sufficient to improve the welfare of society through human development, especially districts/cities as motors implementing the policy. Thus the region can improve the well-being of the community through the improvement [4][5].

The number of poor people and the unemployment rate in North Sumatera were very high. It is considered to keep suppressed the percentage in 2011. Therefore, if these two things are not immediately solved, the impact can cause social unrest and instability at the local level. From late December 2009 to April 2010, distribution of the population who are unemployed are still piled up in urban areas, and the distribution of poor people is still dominant in the countryside. Sumatera needs to do to alleviate the pressure on the performance of these two things. Because of these two things is a priority to do Sumatera by directing development programs to the districts and villages of the poor, as well as the normal pattern of labor-intensive. By performing this pattern, the development program of North Sumatera that is aligned with the national program may be able to increase the availability and repair and maintenance of infrastructure and the existing infrastructure. He mentioned that the number of open unemployment in 2009 in North Sumatera is still registered about 521 thousand people (8.3 percent) of the total workforce. Distribution of the number of unemployed is widely available in urban areas while the rural allocation of the population is poor is still large in 2009 reached 1.5 million people (11.51 percent).

According to the Human Development Report 2005, the number of poor people in Southeast Asia is the Indonesian state of 38.7 million people followed by Vietnam (17:38), Cambodia (13:01) and Myanmar (10.84). Indonesia ranks to 110, lower than in other Southeast Asian countries such as Singapore (25), Brunei Darussalam (33), Malaysia (61), Thailand (73) and the Philippines (84).

To support the economic growth of quality, emphasis must also spur economic growth on average from 
6.3 to 6.8 percent per year, with inflation can be controlled in the range of 4-6 per cent per year in 2011. North Sumatera could achieve economic growth of 6.50 percent in 2011. Due to the growth, it could reduce the number of poor people could be reached 1.37914 million inhabitants. Then increase the literacy rate up to 98.21 percent, and improve HDI to 79.50. Human quality in the region to a large extent determine the success of development management in the region. North Sumatera Province is one of the important provinces in Indonesia because it has some large regional revenue.

The development of the level of fiscal independence that occurred in the district/city in North Sumatera province has a significant impact, especially in the autonomous regions that have gained autonomy. For 2005 amounted to 116.83 , then in 2006 amounted to 140.46 later in 2007 there has been a division amounted to 82.23, for 2008 at 87.17 and for 2009 is 88.69 . This value is obtained from Realization Report Regional Revenue divided by Total Revenues multiplied by one hundred percent.

\section{RELATED WORKS}

The idea of this study was obtained from the research that has been conducted by the Pambudi in 2008 [7]. The title is Analysis of Effect of Fiscal Independence of the Human Development Index of district/city in West Java. The different between this study and the previous research is that He tried to look at the effect of rate Fiscal Independence against the Human Development Index in the district/city of West Java. The location was taken in West Java while the time of research took four years from 2002 to 2006. This research tries to see the effect of regional revenue, fiscal independence level against the Human Development Index through the capital expenditure as an intervening variable in the district municipality of North Sumatera. The Location is in North Sumatera. It takes study for four years from 2005 - 2009.

\subsection{Data Analysis}

\section{METHODOLOGY}

There are two hypotheses, Level of Independence Fiscal, Local Revenue influence simultaneously and partially on the Human Development Index and Rate and Fiscal Independence, Local Revenue influence on the Human Development Index through the Capital Expenditure. The author uses a software-based method of statistical analysis. Data analysis was performed by testing the classical assumptions and hypothesis testing.

Data were analyzed with regression model lines (Path Analysis) as follows:

$$
\begin{gathered}
Y=a+b 1 x 1+b 2 X 2+€ \\
Y 1=a+b 1 x 1+b 2 X 2+b 3 Z+€
\end{gathered}
$$

Where :

$\begin{array}{lll}\mathrm{X} 1 & : & \text { Fiscal Independence } \\ \mathrm{X} 2 & : & \text { Local Revenue } \\ \mathrm{Y} & : & \text { Human Development Index } \\ \mathrm{Z} & : & \text { Capital Expenditure } \\ \mathrm{a} & : & \text { Constants } \\ \mathrm{b} & : & \text { Regression Coefficients } \\ € & : & \text { Error }\end{array}$

The second hypothesis is to see whether the level of independence of the Fiscal effect on the Human Development Index through the Capital Expenditure. This hypothesis using the Baron and Kenny model. The mediating effect occurs if it meets the conditions below:

1. The first independent variable (Level of Fiscal Independence) was significantly associated with the dependent variable (Human Development Index).

2. The second independent variable (the original income) is significantly associated with the dependent variable (Human Development Index).

3. The first independent variable (Level of Fiscal Independence) was significantly associated with an intervening variable (Capital Expenditure).

4. A second independent variable (the original income) is significantly associated with an intervening variable (Capital Expenditure).

5. Intervening variables (Capital Expenditure) significantly correlated with the dependent variable (Human Development Index).

6. The fifth equation is set up to determine the role of Capital Expenditureas a full mediation (intervening full) or intervening part. When the independent variable and intervening variables are controlled, the previously significant relationship between independent variables and the dependent variable was no longer significant or reduced level of significance. 
The second hypothesis tested to prove the effect of intervening.

$$
\begin{gathered}
Y=\alpha 0+\beta 0 X 0+€ Y 1=\alpha 1+\beta 1 X 1+€ \\
Y 2=\alpha 2+\beta 2 Z+€ \\
Y 3=\alpha 3+\beta 0 X 0+\beta 2 Z+€ \\
Y 4=\alpha 4+\beta 1 X 1+\beta 2 Z+€ \\
Z=\alpha 0+\mathrm{O} X 0+€ \\
Z 1=\alpha 1+\mathrm{O} 1 X 1+€
\end{gathered}
$$

\begin{tabular}{lll}
\multicolumn{2}{r}{ Where : } & \\
$\alpha$ & $:$ & Constants \\
$\beta, \mathrm{O}$ & $:$ & Regression Coefficients \\
$€$ & $:$ & Standard error
\end{tabular}

Intervening mostly occur when the effect of the independent variable on the dependent variable after mediated smaller than before mediated and remained significant. Intervening full will happen when the independent variable is not significant effect on the dependent variable after mediated.The significance of alpha $=0: 05$.

Particular Intervening if:

$\beta 0=$ significant

$\beta 1=$ significant

$\beta 2=$ significant, also o $=$ significant

$\beta 3=$ significant but $\beta 3<\beta 0$

Intervening full if:

$\begin{array}{lll}\beta 0 & = & \text { significant } \\ \beta 1 & = & \text { significant } \\ \beta 2 & = & \text { significant, also o = significant } \\ \beta 3 & = & \text { not significant }\end{array}$

\subsection{Normality Test}

Data normality test aims to test whether the regression model of the independent and dependent variables have a normal distribution or not. A good regression model where data distribution is normal or near normal. Normality test detected by looking for distributing data on a diagonal axis of the graph or you can also view the histogram of the residual. If the data is spread around the diagonal line and follow the direction of the diagonal line or histogram graph showing a normal distribution pattern, then the regression model to meet the assumptions of normality, and vice versa.

\section{EVALUATION}

Statistic model 1 shows that the regression with independent variables FIL, LR, and the dependent variable HDI concluded that FIL and LR simultaneously positive and significant influence on $\alpha=0: 05$ to IPM pales FIL and LR increase of 1,000,000 rupiahs, it will increase the HDI of 0.08702 rupiahs. Likewise decrease FIL and LR simultaneously will cause a decrease in HDI. Models created from the results of the regression model 1 is as follows:

$$
Y=72349+0.060 X 1+8.702 E-9 X 2+€
$$

To increase HDI an area, then the government's ability to maximize the performance of its highly charged through increased FIL and LR. So that local revenues derived from the taxes, levies result, profit locally-owned enterprises and other local revenues aim to provide flexibility to the regions in mobilizing funding in the implementation of regional autonomy as a form of decentralization. With the increase in LR will be the creation of a form of HDI which literacy rate, life expectancy, the average length of school and purchasing power.

Likewise, the increase of FIL. The higher the FIL then, the less the allocation of funds provided by the central government to the regions. So that the area had been able to manage the performance of its government and self-realization of regional autonomy.The conclusion of this study simultaneously FIL and LR simultaneously affect the HDI. With total revenues is earned from managing resources well and with confidence the central government to manage its finances, it will realize an independent regional autonomy. 


\subsection{FIL affect the HDI}

The results show that the test of TKF (X1) does not affect the HDI. It is due to the influence of T FIL $\mathrm{KF}$ in the short term is not significant. The results are consistent with research that states FIL was testifying to rural areas is not significant to the HDI, this is because the small reception area, so it does not realize decentralization where the value of adjusted R-square is quite large, namely 0.218 or $21.8 \%$. For a longer time span (over four years) there may be a partial effect on the HDI FIL. FIL measured by total revenues is shared with the local revenue multiplied by one hundred percent. FIL allows the area to be more independent in maximizing the allocation of funds acquired the area to realize a more independent area from central government. If this is true, it will create more advanced areas of decentralization and self-contained.

\subsection{LR affect the HDI}

The test results prove that LR is the partially significant effect on the HDI. The local government should continue to increase its local revenue to meet the needs of the budget for the implementation of its activities. The local government of district/city must increase its income from sources another category of LR both the short-term and in the long-term. From the research results, LR is a local government fund used to meet budgets in district/city that have a significant effect in the short term and the long term against the HDI, because most LR is intended to finance infrastructure and basic public services and speed up development area. This study did not segregate in detail how much LR sourced from the local tax, regional retribution result, profit of local enterprises and other revenue.

\subsection{Full Meditation}

The test results via regression lines indicate that the Capital Expenditure has the positive effect on the level of Fiscal Independence. But not significant to the original income. It can be seen from the results of the test criteria that have been done that Capex is full of intervening variables. It means that capital expenditure only indirectly mediates against FIL, where it require capital expenditures to mediate directly to the HDI. Capital expenditure is expenditure budget used to acquire or increase of fixed assets and other assets that can benefit the public in general. If this public facility can be met in the long term so that people can feel comfortable going to create a good quality education, decent living standards, and purchasing power is high.

However, this study did not separate the Capital Expenditure allocation in the fields of education, health, irrigation, roads, water, marine and fisheries as well as in agriculture. The study also did not know in detail what facilities and infrastructure built by the government that uses Capital Expenditure to district/city of North Sumatera.

\section{CONCLUSION}

Simultaneous hypothesis testing showed that the Fiscal Independence Level and Local Revenue affect on the Human Development Index. Testing the hypothesis partially Regional Revenue significant influence on the Human Development Index. Hypothesis testing is partially Level Fiscal Independence has no effect on the Human Development Index in the district/city of North Sumatera. The results of this study are consistent with previous research. It states that the district of West Java has not been quite independent and had no effect partially on Manusia.Pengujian Development Index hypothesis by using intervening variables stated that the original income direct positive effect on the human development index without going through the Capital Expenditure in the district/city of North Sumatera. Hypothesis testing using intervening variables stated that the level of independence of the Fiscal indirect effect on the human development index through the Capital Expenditure in the district/city of North Sumatera.

\section{References}

[1] Rusiadi, A. Novalina, P. Khairani and A. P. U. Siahaan, "Indonesia Macro Economy Stability Pattern Prediction (Mundell-Flamming Model)," IOSR Journal of Economics and Finance (IOSR-JEF), vol. 7, no. 5, pp. 6-23, 2016

[2] I. Ghozali, Aplikasi Analisis Multivariate dengan Program SPSS, Semarang: Badan Penerbit Universitas Diponegoro, 2009.

[3] Abdullah and Halim, "Pengaruh Dana Alokasi Umum dan Pendapatan Asli Daerah Terhadap Belanja Pemerintah Daerah," in Simposium Nasional Akuntansi, Surabaya, 2004.

[4] T. Libby, "The Influence of Voice Explanation on Performance in a Participative Budgeting Setting," Accounting Organisations and Society, vol. 24, no. 2, pp. 125-137, 1999.

[5] D. Surya, Manajemen Kinerja dan Palsafah Teori dan Penerapannya, Yogyakarta: Pustaka Pelajar, 2009.

[6] Mardiasmo, Akuntansi Sektor Publik, Yogyakarta: Andi offset, 2002.

[7] S. B. Pambudi, Skripsi : Analisi Pengaruh Tingkat Kemandirian Fiskal terhadap Indeks Pembangunan Manusia Kabupaten/Kota Provinsi Jawa Barat, Bogor: Institut Pertanian Bogor, 2008. 